\title{
Developing Achievable Completion Criteria for Fauna - Can it be Done?
}

\author{
O.G. Nichols Environmental Management and Research Consultants, Australia
}

\begin{abstract}
Considerable effort is being made by mining companies to develop completion criteria for native ecosystem rehabilitation, based on sound ecological principles. However to date, criteria have largely focused on vegetation communities, with comparatively little attention paid to the development of achievable completion criteria for fauna. This paper reviews relevant fauna studies in the mining industry and illustrates how these are being used to develop workable completion criteria.
\end{abstract}

Studies show that mines developing completion criteria for fauna can face significant challenges. Monitoring data reveal considerable variability in the rates at which fauna recolonize mine rehabilitation. This can be due to factors specific to the group being studied, such as mobility, method of dispersal, and habitat requirements. However, it can also be due to variations in the numbers present in surrounding source populations, the presence of predators (both native and feral), and the extent to which its habitat requirements are being fulfilled in the newly rehabilitated area.

Detailed fauna research programs in the Australian bauxite and mineral sand industries, together with monitoring at other mines in Australia and elsewhere, show that the processes of faunal recolonization can be understood and completion criteria developed by adopting a systematic approach to the selection of agreed rehabilitation objectives, implementation of monitoring and research programs, and from these, developing achievable completion criteria, standards and milestones.

This paper utilizes various examples to show that, whilst several companies have developed completion criteria for fauna, caution is warranted if mines are to avoid setting criteria that may prove difficult to assess, or unattainable milestones.

\section{Introduction}

There is now widespread recognition in the mining industry of the need for completion criteria in order to determine when site rehabilitation is successful from the viewpoint of mining companies, regulators and the community. Considerable effort is being made to develop completion criteria for native ecosystem rehabilitation, based on sound ecological principles. However to date, criteria have largely focused on vegetation communities, with comparatively little attention paid to the development of achievable completion criteria for fauna, despite the fact that fauna are integral to the development and functioning of sustainable native ecosystems. For example, in a developing ecosystem, fauna play key roles in determining soil physical structure (through burrowing and aeration) and chemical properties (through nutrient cycling), as well as vegetation composition (through seed dispersal and germination, pollination and grazing). Establishment of healthy vegetation cover and associated soil fauna increase a site's physical stability. With increasing recognition of the importance of biodiversity conservation in the environmental management of mining operations (ICMM, 2006; DITR, 2006), leading practice now requires that companies conserve fauna wherever possible, minimize any impacts and re-establish fauna populations following mining. Sustainability of rehabilitation is a key element of mining sustainable development, and fauna play a major role in ensuring rehabilitation is sustainable, and act as important indicators of sustainability.

Given all of the above roles, it is clear why the development of completion criteria for fauna is important in the overall process of obtaining sign-off for native ecosystem rehabilitation. Agreed fauna criteria are needed to satisfy stakeholders that objectives have been met. They also help demonstrate likely long-term sustainability, and serve as indicators of the development of other aspects such as vegetation structure and diversity (Majer et al., 1984; Nichols, 1998; Nichols and Nichols, 2003). 
This paper presents findings from relevant fauna and related studies conducted predominantly in the Australian mining industry. It illustrates how these are being used to develop workable completion criteria.

\section{Challenges faced when developing completion criteria for fauna}

Mining companies attempting to develop completion criteria and any associated milestones and standards for fauna face a number of challenges, some of which relate to rehabilitation in general, and some that are specific to fauna.

One of the more difficult challenges relates to the fact that many fauna groups recolonize mine rehabilitation at different rates, so in most cases it is not possible to select a single species or group as an indicator of rehabilitation success, from a fauna viewpoint. For example, Figure 1 shows monitoring results for three native and one introduced mammal species in Alcoa's rehabilitated bauxite mines over a period of nine years from age two to age 11. Percentage trap success for Mardos (a small carnivore) only increases slowly and remains lower than in unmined forest, however it should be noted that subsequent data for 2006 (Alcoa unpublished results) show that at the age of 15 years, abundance of Mardos increased to 4.1. It is thought that a key reason for the species' slow recolonization is the limited availability of shelter in the form of logs, stumps, etc. By contrast, the abundance of Quenda (an omnivore) reflects that in unmined forest at a much earlier rehabilitation age, due to the suitability of young rehabilitation for this species, and the fact that under favorable conditions it can breed rapidly compared to many other forest mammal species. Common Brushtail possums are folivores, and would not be expected to colonize rehabilitation until trees reach an age at which the species can feed. Figure 1 suggests this age is around 11 years, while subsequent monitoring data for 2006 show possum numbers higher than those in unmined forest (Alcoa unpublished results), possibly due to a preference for new leaves on the younger trees. However, possums also require hollow trees for shelter and breeding purposes, and these will not develop in rehabilitated areas for many years. Thus, for the time being, possums are restricted to feeding in rehabilitation and sheltering in unmined forest, so overall their rate of recolonization is intermediate to that of other species. Feral mice act as a disturbance indicator (Nichols and Grant, 2007) and readily colonize burnt forest and young mine rehabilitation. In time, their numbers decline and they are present in very low numbers unless rehabilitation is burnt, in which case there is a temporary increase in abundance. Overall, these examples show that the extent of colonization depends on factors such as species' mobility, breeding rates, and their feeding and shelter requirements.

Together, the results clearly demonstrate that it would be impossible to use one of these species to develop a quantitative target for overall mammal rehabilitation success, as part of any completion criteria. Long-term monitoring of mammal recolonization at mineral sands mines in NSW (Fox, 1996) show similar variability between mammal species. However, both studies do indicate that it is possible to develop an understanding of the rates different species recolonize, and the processes that influence their recolonization. This is important in understanding overall ecosystem development, and can be integrated into more general criteria, as discussed later in this paper.

Other fauna groups illustrate different aspects of recolonization. For birds, the numbers of species and diversity in rehabilitated bauxite mines match those in unmined forest by age eight years (Figure 2). However, it is clear from these two graphs that in any one year, there can be considerable variability between both rehabilitated and unmined reference sites. For the reference sites, this variability can increase depending on which vegetation types are selected (in this case, forest typical of that mined was chosen), seasonal variation, and disturbances such as fire, dieback, and human impacts such as logging. Therefore, even in a relatively straightforward example such as this where the two indicators measured (species numbers and diversity) increase rapidly to match those in the reference sites, it would be very difficult to set specific values for either indicator that would demonstrate rehabilitation success in all instances likely to be encountered.

Further complications can arise when attempting to develop specific targets by comparing trends in rehabilitated and unmined areas. Predation by introduced species such as the European fox has had a significant impact on many medium sized mammal species in Australia. Control of foxes through baiting can result in significantly greater numbers of many native mammal species in unmined areas. As these areas provide the source populations for recolonization of mined areas, the extent of recolonization can depend on the extent and effectiveness of fox control (Nichols and Nichols, 2003). Developing specific targets for 
susceptible species would need to take this into account, which would be extremely difficult as the abundance of source populations would vary between species (reflecting different rates of recovery in response to baiting) and over time (due, for example, to species breeding rates).
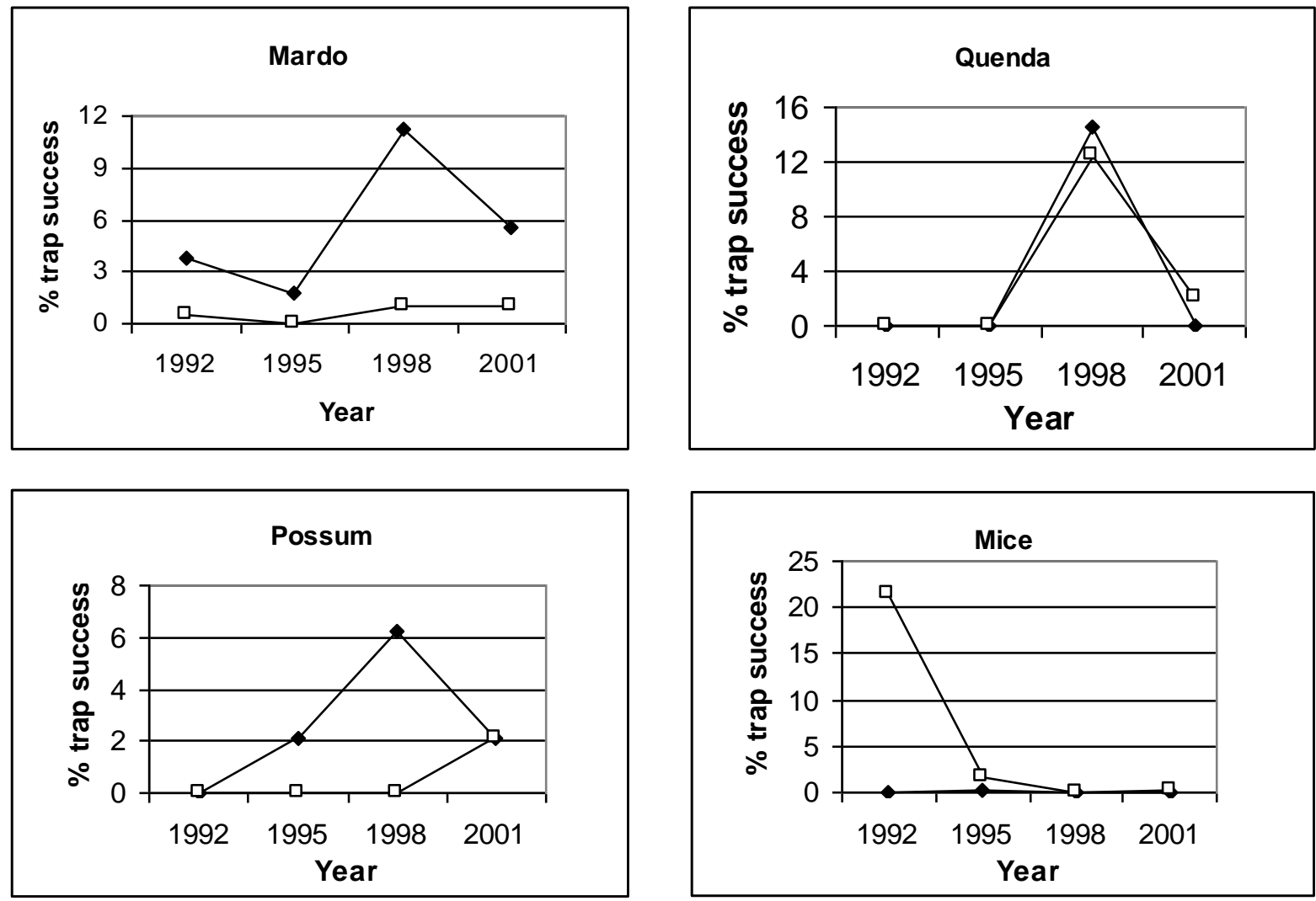

Figure 1 Total numbers of Mardos, Quenda, Brushtail possums, and feral mice recorded in 1990 rehabilitation ( $\square$ ) and in healthy unmined forest ( $\diamond)$ at Alcoa (Nichols and Grant, 2007)
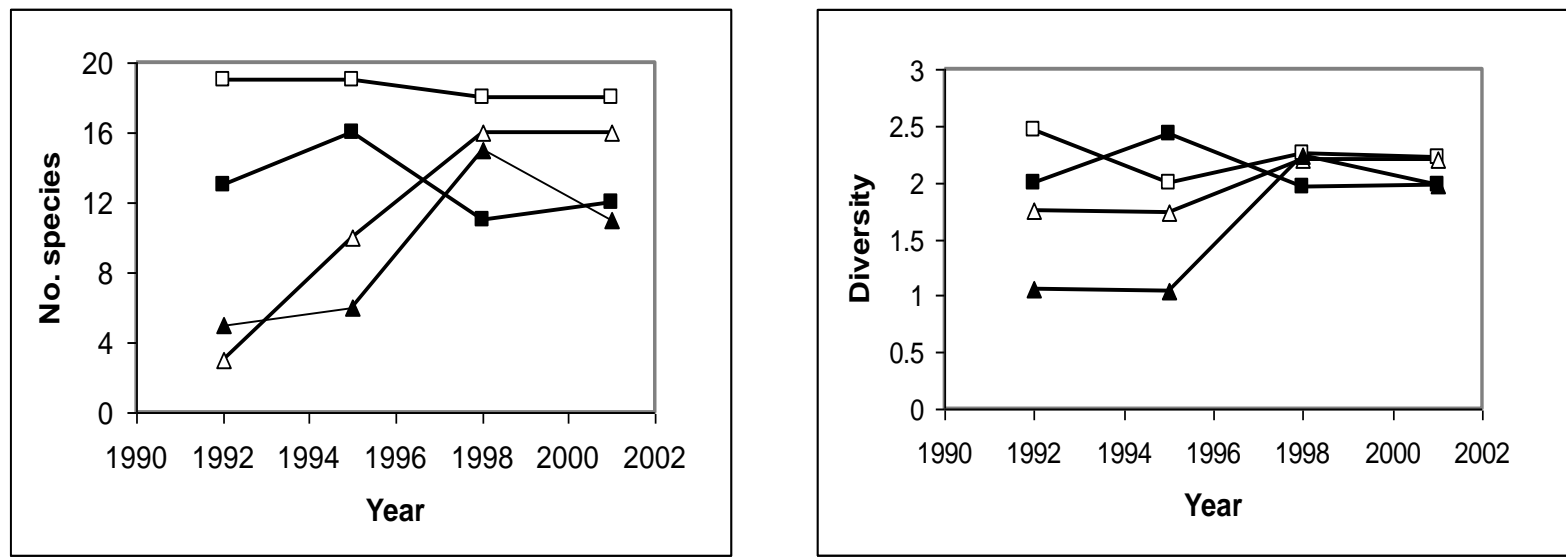

Figure 2 Total numbers of bird species and bird diversity (Shannon-Weiner) recorded in summer at Jarrahdale mine in 1990 rehabilitation ( $\Delta$ rehabilitation 1; $\Delta$ rehabilitation 2) and in healthy unmined forest ( $\square$ forest 1; $\square$ forest 2) sites at Alcoa. Surveys at each site were conducted along two $250 \mathrm{~m}$ transects on three occasions, recording all birds within $20 \mathrm{~m}$ of the transect (Nichols and Grant, 2007)

Other impacts that complicate the assessment of fauna recovery following mining include grazing (in both mined and unmined areas) and hunting, both by Europeans for recreation, and indigenous peoples. Grazing can significantly alter the structure and floristics of vegetation communities, and therefore affect faunal 
composition and abundance, while hunting can significantly decrease numbers of target species. Any disturbances such as these create further statistical 'noise' which makes it very difficult to understand and predict trends in species recovery, and therefore develop completion criteria with achievable targets.

In some cases, studies of individual species and the development of specific targets may be justified. Examples could include rare or threatened species, and species with particular cultural significance to indigenous peoples, or 'iconic' species for which have widespread public appeal. Surveys of such species can be technically difficult, time consuming and expensive, but may be necessary due to stakeholder preferences or regulatory requirements. Some examples are given in the flora and fauna management plan (FFMP) developed for Xstrata Coal's Mt. Owen Mine in New South Wales (Xstrata Coal, 2006). This has been developed in conjunction with a biodiversity offset strategy (Umwelt, 2003) required to obtain approval to clear an area of remnant vegetation. The FFMP requires detailed monitoring of key species in both unmined areas (to assess impacts of mining and related operations) and rehabilitation (to assess recovery of populations). It also requires offset actions such as the establishment of nest boxes for hollow nesting species, and creation or restoration of wetlands for frog populations. The Mt Owen FFMP is a very good example of how, for fauna, it is often necessary to take a whole of lease perspective to achieve good fauna conservation and recovery. General completion criteria have been developed as part of the biodiversity offset strategy to determine whether it effectively offsets the values impacted. More specific ecological completion criteria are currently being developed for both mine rehabilitation (as part of the mine closure plan) and unmined areas reafforested as part of the offset strategy.

A number of detailed studies have been conducted on invertebrate recolonization of rehabilitated mined areas, and in many cases these illustrate challenges relating to sampling methods and taxonomy. However, they also emphasize the importance of invertebrates in key ecosystem functions such as nutrient cycling and pollination. Invertebrate monitoring in bauxite mines is summarized in Majer et al. (2007), while data from mineral sand mines and bauxite mines are summarized in Majer et al. (2006). Studies such as these demonstrate the potential use of invertebrate groups such as ants, spiders, termites, collembola and others as indicators of rehabilitation success, however to date it appear that no mining company has adopted any specific invertebrate parameter as a completion criteria.

\section{Suggested approach for developing achievable completion criteria for fauna}

Despite the difficulties described above, it is possible to develop achievable completion criteria for fauna, and associated standards and milestones. However, as noted in Section 2, in most cases it is difficult or impossible to develop very specific, quantitative targets (or milestones), such as a designated species richness value, a given fauna density or diversity, etc. that may or may not be achieved depending on a complex range of circumstances, some of which will be outside the control of the mining company. Instead, it is recommended that detailed fauna studies be undertaken as part of a whole ecosystem approach to understanding the successional processes taking place, and from this, achievable criteria be developed as suggested in Section 3.6, with examples shown in Section 4. The process should involve the following steps.

\subsection{Understand fauna species ecology and habitat requirements}

Both the ICMM Good Practice Guidance for Mining and Biodiversity (ICMM, 2006) and the DITR Leading Practice Handbook on Biodiversity Management (DITR, 2006) strongly emphasize the importance of baseline surveys and monitoring. With regards to fauna, the knowledge gained enables mining companies to assess the type and extent of impacts on species (and therefore what remedial actions may be necessary), and, by knowing what species are present and their habitat requirements, design cost-effective rehabilitation programs that will replace fauna habitat and enable species to recolonize to the greatest practicable extent. Where possible, this information should be obtained prior to mining related disturbance taking place. However, in many cases pre-mining surveys have not been conducted and in these instances, the necessary information must be obtained from literature surveys of the fauna species and groups concerned, related studies (e.g. surveys of similar unmined areas and mine rehabilitation), and by conducting surveys of unmined habitat representative of the areas mined. 


\subsection{Set achievable objectives for fauna}

EMRC (2004; 2005) and Nichols (2006) state that completion criteria for native ecosystem mine rehabilitation should be developed as part of a process that involves the following steps: Set achievable rehabilitation objectives in consultation with key stakeholders; implement leading practice mine rehabilitation; monitor to assess development of the rehabilitated ecosystem and implement continuous improvement; and develop completion criteria in consultation with stakeholders, based on what the results show to be achievable. This approach is being adopted by an increasing number of mining companies in Australia (e.g. Xstrata Coal NSW, Collie Coal Mining Companies, Consolidated Rutile Ltd and other mineral sand mining operations) and is being considered by PT Freeport Indonesia and Tiwest's mineral sand mine in Western Australia. A key step in the process is the development of rehabilitation objectives that reflect leading practice, whilst at the same time recognize any technical limitations to what rehabilitation operations can achieve. The rehabilitation objectives can, and should, include specific faunal objectives.

Depending on the importance of conservation as an end land-use, and whatever technical limitations may exist, rehabilitation objectives pertaining to fauna could include:

- Aiming for complete ecosystem restoration, including the recolonization of all fauna species in similar densities to unmined sites.

- Recolonization of most species, including those known to have important functional roles.

- Providing important habitat for one or more species or groups e.g. rare species, wetlands for waterbirds, roosting sites for bats.

- Providing habitat for uncommon or declining species.

- Establishing a stable, self-sustaining vegetation community with habitat value for some native fauna species.

In most cases the objective chosen will depend on a variety of considerations. These may include need - for example, in areas where the pre-mining habitat is relatively degraded but common and widespread, there may be the opportunity to establish a habitat for which, from a fauna viewpoint, the need is much greater. For example, near Kwinana in WA, Alcoa established wetlands in clay mined areas where the previous vegetation had been largely cleared, but there was a great need for wetlands as most of these in the region had been drained, cleared and used for agriculture, housing and other purposes. The resulting wetlands support large numbers of waterbird and aquatic invertebrate species and compare favorably with natural wetlands (Nichols and McIntosh, 1998). Other important considerations include technical limitations. For example, it may not be possible to propagate some plant species important for fauna habitat. Some mine tailings pose particular rehabilitation challenges in relation to soil chemical and physical properties, however fauna can serve an important function here as well, through the gradual development of the soil profile. Finally, cost is usually a factor in determining objectives. All of these need to be taken into consideration in conjunction with regulators and other stakeholders.

Fauna objectives will usually need to reflect a whole of lease approach, due to the mobility of fauna. In many cases, the objectives will also need to include consideration of offsets, or trade-offs, such as those developed by Xstrata's Mount Owen Mine (noted earlier).

Once objectives have been developed, these can then form the basis of the monitoring program, which should be designed to determine progress towards meeting the objectives. Following this, completion criteria and target standards and milestones can be developed based on the objectives, and what monitoring shows to be achievable.

\subsection{Identify key faunal indicators and implement monitoring programs}

Key faunal indicators are those that, for particular species or groups, measure key aspects of the developing rehabilitated ecosystem, such as the re-establishment of significant species, groups, or ecosystem functions (such as pollination, seed dispersal or nutrient cycling). They can include both vertebrates and invertebrates. Factors that should be taken in to account when selecting faunal indicators include: 
- Their suitability for monitoring (ease of recording, presence of adequate numbers for statistical analyses).

- Ecological function - in which processes do they serve an important role?

- Early successional stage native species colonizers.

- Late successional stage colonizers (i.e. species that require specific habitat characteristics that do not develop for many years).

- Species important for one or more human uses e.g. food, cultural significance, medicinal purposes, particularly in areas where traditional uses are still common, such as the recently closed Misima mine in Papua New Guinea (Jasper et al., 2003).

- Feral species, which can indicate the degree of disturbance to both unmined and rehabilitated ecosystems.

As an example, detailed fauna studies conducted by Alcoa (Nichols, 2006) have focused on groups that indicate key aspects of biodiversity and ecosystem function such as birds (vegetation structure, floristics and insect abundance), reptiles (presence of ground shelter and invertebrates), spiders (vegetation structure and suitable prey), ants (pollination, soil aeration), collembola, mites and termites (nutrient cycling). Together, these studies have provided a detailed understanding of ecosystem development, and enabled Alcoa to develop and set criteria that meet the expectations of regulators and other stakeholders.

Other fauna studies have also been conducted at Alcoa to assess the response of vertebrate (Nichols and Nichols, 2003) and invertebrate (Brennan, 2002) fauna to burning. As a general rule, these show good recovery of key components of the rehabilitated forest ecosystem following fire, and indicate that the system is likely to be sustainable in the longer term. Together, this information has enabled the WA Government and other stakeholders to confidently sign off on an agreed mine closure process.

Jasper et al. $(2003 ; 2006)$ reviewed the use of faunal indicators in relation to measuring post-mining recovery of native ecosystems in tropical rain forest communities. Although very few relevant studies had been conducted, several provided useful information on the processes of faunal colonization. These included Majer's $(1992 ; 1996)$ detailed studies of ant recolonization following rehabilitation of bauxite mined areas at Trombetas and Poços de Caldas, in Brazilian rain forest. In Indonesia, Passell (2000) surveyed birds in one to three year old restored tin mine areas and in secondary forest reference sites, while EMRC (1999) recommended that key groups of birds, mammals, reptiles, frogs, ants and termites be monitored in rehabilitation at Kaltim Prima Coal's mine in East Kalimantan. Jasper et al. (2003) concluded from the review that no single indicator can be used to illustrate trends in all faunal groups. They noted that although it has been demonstrated on particular mines that correlations exist between some measured parameters of the mammal fauna and some vegetation parameters, in most cases it is not known in advance what these correlations are, so it is not possible to use mammal survey data alone as a surrogate of any particular ecosystem parameter. By contrast, several studies of bird recolonization of mined areas have demonstrated positive statistical associations between measured bird community parameters and particular plant parameters, especially plant productivity and floristic diversity. Based on the earlier review, Jasper et al. (2006) concluded that the following fauna parameters were likely to be the most suitable for use in monitoring rehabilitation of tropical forest ecosystems: bird species richness, total bird abundance; bird species diversity; presence/absence of early, mid, or late colonizing bird species; density of key mammal species; ant species richness, and total ant abundance.

Based on the above, it can be concluded that the following aspects and parameters should prove the most useful in monitoring the recovery of fauna habitat, species and populations:

- Habitat condition and recovery.

- Trends in the numbers or diversity (as opposed to specific target values) of fauna species or groups that serve important defined functions.

- Recovery of significant individual species, e.g. rare, threatened or uncommon species. 
- Sustainability under defined land-uses and management prescriptions, and recovery following fire, drought etc.

Mining companies that conduct detailed monitoring programs for one or more fauna groups include:

- Alcoa's bauxite mining operations - long term vertebrate (Nichols and Grant, 2007) and invertebrate (Majer et al., 2007) monitoring programs.

- Tiwest and Iluka's mineral sand mining operations in Western Australia - vertebrate and invertebrate monitoring (Majer et al., 2006).

- PT Freeport Indonesia's gold and copper mining operations - detailed soil invertebrate monitoring.

- Worsley Alumina's bauxite mining operations in Western Australia - vertebrate and invertebrate fauna monitoring.

- Rio Tinto Coal's Blair Athol mine in Queensland - vertebrate monitoring.

The monitoring procedures described earlier and utilized by these companies, together with the results of these monitoring programs, can be used to develop completion criteria, as illustrated in Section 3.6.

\subsection{Utilize a whole of lease approach for fauna management and monitoring}

Managing for the purposes of fauna conservation requires that differences between species habitat requirements, mobility and other aspects be taken into account. Many species require different habitats to cater for different stages of their life cycle, or daily requirements; for example, many parrot species can feed in small shrubs in heathlands but require tall trees in woodlands for roosting at night. Mining companies that place high priority on fauna conservation adopt the approach recommended in DITR (2006), by viewing fauna management from a 'whole of lease' perspective, or more correctly, a whole of landscape perspective. This is designed to ensure that, to the extent possible, the habitat needs of species recolonizing rehabilitation are taken into account. The example described in Section 2 of possums recolonizing bauxite mined areas at Alcoa illustrates that this species utilizes both rehabilitated areas for feeding, and large trees with hollows for sheltering. Without conserving adequate habitat trees in the surrounding forest, it would not be possible for this species to recolonize. The same is true for numerous bird species such as parrots that feed in rehabilitation but breed in mature or hollow trees. Therefore, for companies such as Alcoa, conserving areas of jarrah forest is an important component of their overall biodiversity conservation program, and must be linked closely to objectives, monitoring, and completion criteria. Other examples include Ranger Uranium Mine in the Northern Territory, which controlled numbers of introduced buffalos and enabled degraded wetlands to recover, and BHP Billiton's Olympic Dam mine, which has excluded introduced predators from large areas and enabled the reintroduction of many native mammal species including several rare species.

The approach adopted by companies in some cases includes formal offsets, or tradeoffs. These may be designed to fulfill fauna habitat requirements until rehabilitation reaches the age where it caters for the habitat requirements of target species. A good example of formal offsets that take a whole of lease approach and link to rehabilitation is that of Xstrata (Umwelt, 2003). General aspects relevant to offsets and mining operations are described in ICMM (2005). Detailed discussion of offsets is beyond the scope of this paper, however, it is important to note that they are relevant to the development of completion criteria and must be taken into account.

References sites used for monitoring purposes are another integral component of the whole of lease perspective. The understanding of species habitat requirements and ecosystem successional trends gained through monitoring carefully selected reference sites is essential for developing rehabilitation procedures and completion criteria. It is also important for understanding sustainability of rehabilitation. Alcoa's approach to demonstrating sustainability of the developing ecosystem has focused on interpreting and understanding the findings of successional and nutrient cycling studies (EMRC, 2004). The rehabilitated system is considered likely to be sustainable if it matches the unmined forest in key aspects, and/or no problems are apparent. Thus, rehabilitation that matches the unmined forest in plant species richness and ecological function, recovers from disturbances such as fire, and supports comparable populations of key faunal groups, is considered likely to be sustainable. 


\subsection{Link fauna monitoring and research to vegetation monitoring}

The role of fauna in developing rehabilitated ecosystems is described in Section 1. From this it is obvious that both fauna and flora re-establishment happen in parallel, with each influencing the other. Some studies, such as Majer et al. (1984) have shown significant statistical correlations between key invertebrate parameters and vegetation parameters such as cover, species richness, and diversity. Other studies demonstrate links between the structural and floristic development of vegetation, and bird species richness and diversity (Nichols and Nichols, 2003). However, as noted in Jasper et al. (2003), there is considerable variability in the links between fauna species and groups, and vegetation communities. For this reason it is not possible to use vegetation parameters as surrogate measures of fauna colonization. Rather, it is important that the development of both fauna and vegetation communities be monitored in order to understand and manage the development of the whole ecosystem, as well as develop achievable completion criteria and monitor progress towards achieving them.

Fauna and vegetation together play an important role in the development of the soil profile, and for this reason monitoring of some fauna groups, such as collembola, termites and earthworms should be linked to soil chemical and physical properties as well as vegetation parameters such as cover, biomass and litter. At Alcoa, detailed studies have been undertaken on collembola, termites and ants (Majer et al., 2007) while at PT Freeport Indonesia's mine, soil invertebrate surveys are conducted annually in a number of rehabilitated and unmined reference sites.

\subsection{Use data obtained from flora and fauna monitoring to develop completion criteria}

In Section 2, it was demonstrated that in most cases it is very difficult and in some cases impossible to develop specific, achievable quantitative targets or milestones as part of a set of completion criteria for fauna. Despite this, in some instances there will be rare or culturally significant species for which, despite the difficulties involved, specific criteria have to be developed to ensure their recovery, and/or meet regulatory and stakeholder requirements.

In general, when developing completion criteria for fauna, it is preferable to focus on ensuring that leading practice rehabilitation standards have been implemented, key aspects of the ecosystem such as fauna habitat are developing satisfactorily, and key faunal and other biodiversity indicators are trending in the right direction at an acceptable rate. Thus, appropriate fauna criteria, standards and milestones could include those that provide a measure of the following aspects:

- Native vegetation in surrounding areas has been protected and enhanced where possible, to conserve fauna populations and therefore maintain sources of fauna recruitment.

- Verification that key elements of fauna habitat establishment have been carried out during rehabilitation operations, such as the establishment of native vegetation, addition of fauna habitat features such as logs, rock piles, nest boxes, raptor perches, vegetative material etc. according to agreed defined prescriptions.

- Evidence that the vegetation community is developing structure, diversity, floristics, phenology, cover, litter layers etc. suitable for recolonizing fauna populations.

- Measures of key vertebrate and invertebrate fauna indicators such as density, species richness and diversity indicate that these are trending towards values recorded in one or more representative unmined reference sites (recognizing that natural variability usually exists in unmined areas, and which vegetation type rehabilitation will develop into is seldom known to any great extent).

- Monitoring includes some measure of sustainability of flora and fauna communities under defined post-mining management regimes, e.g. management for conservation, or limited traditional use, sustainable grazing, etc.

- Monitoring assesses resilience of floral and faunal communities to natural disturbances such as fire, drought, etc.

- Some measure of whether offsets or tradeoffs relevant to fauna conservation and recovery are needed. 
Whilst they may not include specific quantitative targets, criteria based on the above measures would provide a high level of assurance that biodiversity values are re-establishing satisfactorily within an acceptable time frame.

The following sections provide some examples of fauna related criteria either already adopted by mining companies, or proposed and being considered.

\section{Examples of fauna and related completion criteria}

A number of mining companies have developed rehabilitation completion criteria whilst others are in the process of doing so. Some of these criteria are directly relevant to fauna, whilst others are indirectly relevant, for example they require that fauna habitat meets certain standards. The examples are presented by company.

\subsection{Alcoa World Alumina Australia}

The complete set of completion criteria for Alcoa's rehabilitated bauxite mines in Western Australia can be found at http://www.mpr.wa.gov.au/documents/investment/BauxiteMineRehab.pdf. Those directly or indirectly relevant to fauna are listed in the table below. It should be noted that the criteria are divided into temporal stages of the mining operation, viz. planning, very early, early, mid and late. The process is described in more detail in EMRC (2005).

Table 1 Examples of Alcoa completion criteria directly or indirectly relevant to fauna

\begin{tabular}{|c|c|c|}
\hline Stage & Criteria & Standard Required \\
\hline \multirow[t]{2}{*}{ Planning } & $\begin{array}{l}\text { Has a land-use plan been agreed with the } \\
\text { government? }\end{array}$ & Area has a designated land-use. \\
\hline & $\begin{array}{l}\text { Has a rehabilitation plan been developed which } \\
\text { identifies how the area will be revegetated? }\end{array}$ & $\begin{array}{l}\text { All vegetation requirements are } \\
\text { catered for in the plan. }\end{array}$ \\
\hline Very early & $\begin{array}{l}\text { Does the region (i.e. rehabilitated area) have } \\
\text { adequate fauna habitat? (i.e. log habitat piles). }\end{array}$ & $\begin{array}{l}\text { No. of habitats per hectare based on } \\
\text { regional assessment as per } \\
\text { silviculture specification } 1 / 95 \text {. }\end{array}$ \\
\hline \multirow[t]{2}{*}{ Early } & $\begin{array}{l}\text { Is there an appropriate understorey species } \\
\text { richness? }\end{array}$ & $\begin{array}{l}\text { Richness is a minimum of } 70 \% \text { of } \\
\text { forest controls based on } 15 \text { month } \\
\text { monitoring. }\end{array}$ \\
\hline & $\begin{array}{l}\text { Are there any bare areas other than sumps greater } \\
\text { than } 0.5 \text { of a hectare? }\end{array}$ & $\begin{array}{l}\text { There are no areas greater than } 0.5 \\
\text { of a hectare with less than } \\
1 \text { legume } / \mathrm{m}^{2} \text {. }\end{array}$ \\
\hline Mid & $\begin{array}{l}\text { Are there adequate stocking rates of eucalypts and } \\
\text { understorey species capable of regenerating after a } \\
\text { wildfire? }\end{array}$ & $\begin{array}{l}\text { The site is capable of recovering } \\
\text { from a wildfire. }\end{array}$ \\
\hline \multirow[t]{2}{*}{ Late } & $\begin{array}{l}\text { Are there adequate numbers of both jarrah and } \\
\text { marri trees? }\end{array}$ & $\begin{array}{l}\text { Minimum of } 300 \text { stems per hectare } \\
\text { with the potential to produce trees } \\
\text { with sawn timber potential. }\end{array}$ \\
\hline & $\begin{array}{l}\text { Is the area being preferentially attacked by insects? } \\
\text { If so, is insect damage causing adverse impact on } \\
\text { the health of the plant. }\end{array}$ & No minimum standard. \\
\hline
\end{tabular}

Note that even after more than 30 years of fauna monitoring and research, there are no specific quantitative fauna targets, due to the variability in rates of recolonization as well as between unmined sites, and other factors mentioned in Section 2. Nevertheless, in conjunction with the detailed vertebrate and invertebrate fauna monitoring and research conducted (Nichols and Grant, 2007) and reported to government and stakeholders in annual reports and numerous scientific publications, the criteria are designed to give reassurance that fauna recolonization will be satisfactory within an acceptable time frame. 


\subsection{Anglo Coal's Callide Mine}

Anglo Coal's Callide Mine was one of two mines used as a case study in a project designed to establish an agreed process for developing native ecosystem rehabilitation completion criteria for coal mines in Queensland's Bowen Basin coal mining area. The process and the resulting criteria developed for Callide are described in EMRC (2004). In Callide's case, completion criteria were needed to meet a Government condition that completion criteria be developed by a specified date. The resulting criteria fulfilled that condition. Those criteria relevant to fauna are listed below. As with the previous Alcoa criteria, they are grouped together in stages of the mining operation. In the case of the Callide criteria below, all are from the development and sign-off stage.

\section{Table 2 Examples of Callide completion criteria directly or indirectly relevant to fauna}

\begin{tabular}{|c|c|}
\hline Criteria & Standard or Milestone Required \\
\hline Tree density & $\begin{array}{l}\text { Monitoring or visual estimation show the density of trees }>1.6 \mathrm{~m} \text { tall to be } \\
>100 \mathrm{stems} / \mathrm{ha} \text {. }\end{array}$ \\
\hline Grasses & Native grass species are present. \\
\hline Shrubs & A range of native shrub species are present. \\
\hline Fire tolerance & $\begin{array}{l}\text { Tree, understorey and grass species are capable of either surviving or } \\
\text { regenerating following a fire. }\end{array}$ \\
\hline Drought tolerance & $\begin{array}{l}\text { Tree, understorey and grass species are capable of surviving drought, as } \\
\text { demonstrated by recent monitoring and research results (following a period } \\
\text { of severe drought from 2001-2003). }\end{array}$ \\
\hline Sustainability & $\begin{array}{l}\text { Monitoring and research results indicate that the rehabilitation is likely to be } \\
\text { sustainable over the long-term, if managed according to agreed procedures. }\end{array}$ \\
\hline Fauna habitat & $\begin{array}{l}\text { Fauna habitat matches that in some surrounding woodland areas or will do so } \\
\text { in time. }\end{array}$ \\
\hline Diversity of vegetation & $\begin{array}{l}\text { Includes a range of vegetation structural habitats, e.g. eucalypts, shrubs, } \\
\text { ground cover and a developing litter layer. }\end{array}$ \\
\hline $\begin{array}{l}\text { Fauna recolonization - } \\
\text { invertebrates }\end{array}$ & $\begin{array}{l}\text { Studies demonstrate that key invertebrate functional groups such as ants and } \\
\text { soil faunal communities are re-establishing. }\end{array}$ \\
\hline $\begin{array}{l}\text { Fauna recolonization - } \\
\text { vertebrates }\end{array}$ & $\begin{array}{l}\text { Vertebrate surveys demonstrate that bird, mammal, reptile and frog } \\
\text { communities are becoming established in rehabilitated sites. }\end{array}$ \\
\hline $\begin{array}{l}\text { Management of fauna } \\
\text { habitat in unmined areas }\end{array}$ & $\begin{array}{l}\text { Where possible, fauna habitat of adjacent unmined areas will be protected } \\
\text { from clearing and grazing as part of Callide's overall lease management } \\
\text { program, and disturbed areas will be allowed to regenerate (e.g. The Hut } \\
\text { Reforestation Project Area). Such areas constitute sources of recruitment for } \\
\text { both fauna and flora to rehabilitation. }\end{array}$ \\
\hline $\begin{array}{l}\text { Management of rare } \\
\text { species habitat }\end{array}$ & $\begin{array}{l}\text { Habitat of any rare or vulnerable fauna species recorded is managed to } \\
\text { promote the species conservation where not on the mining path. }\end{array}$ \\
\hline $\begin{array}{l}\text { Suitability for nature } \\
\text { conservation }\end{array}$ & $\begin{array}{l}\text { Areas of rehabilitation and unmined sites within the lease, including The Hut } \\
\text { Reforestation Area, together possess defined conservation values and could } \\
\text { be managed for the purposes of conserving a range of local flora and fauna } \\
\text { species and vegetation types, including the rare plant species identified. }\end{array}$ \\
\hline
\end{tabular}

It should be noted that, compared to the Alcoa completion criteria, these contain more detail. One reason for this is because, although fauna surveys of surrounding areas have been conducted at Callide, apart from some ant monitoring, at the time there had been no detailed monitoring of fauna recolonization of rehabilitation. This was reflected in criteria such as those that required studies to be carried out, and indicate satisfactory fauna recolonization. 


\subsection{Other examples of completion criteria}

As well as the above two examples, other companies have developed completion criteria that apply either directly or indirectly to fauna.

For example, CRL has developed relatively detailed rehabilitation monitoring programs and completion criteria (Nichols and Foot, 2002; EMRC, 2005). Fauna habitat requirements are taken into consideration in the rehabilitation prescription, with specific fauna related techniques including the transplanting of grass trees (Xanthorrhoea johnsonii), and establishment of fauna log habitats, raptor perches, nest boxes and stags (old dead trees with hollows suitable for fauna shelter). However, at this stage completion criteria focus only on vegetation, although the importance of the vegetation in establishing fauna habitat is recognized. Currently, there are no fauna completion criteria that define specific quantitative targets for any fauna species or group, and no plans to develop any.

Xstrata's Mount Owen Mine is in the process of developing criteria both for offset areas (see Section 2) and for rehabilitation in general. Criteria for offset areas will contain specific criteria and targets for particular rare fauna species, while it is likely that those for rehabilitation will be more general, due to the uncertainties involved.

\section{Conclusions}

It is clear from the examples quoted in this paper that an increasing number of mining companies are conducting detailed monitoring of fauna recolonization into rehabilitated areas. This is providing valuable information on the effectiveness of rehabilitation techniques in restoring biodiversity values. However, monitoring data are also showing that considerable variability exists between fauna groups and even between species in the rates at which they colonize, whilst fauna populations also vary between reference sites that are used to gauge the extent of recovery in rehabilitation. These and other limitations make the development of specific completion criteria for fauna very difficult. However, projects conducted to investigate the development of completion criteria, and examples of the approaches used by several mining companies show that achievable criteria, standards and milestones that are directly and indirectly relevant to fauna can be developed. Provided care is taken in developing these criteria, and they are based on the findings of soundly designed monitoring programs, it is likely that meeting them will demonstrate that rehabilitation objectives have been fulfilled to the agreement of regulators and other key stakeholders.

\section{References}

Brennan, K. (2002) The Successional Response of Spider Communities Following the Multiple Disturbances of Mining and Burning in the Western Australian Jarrah Forest. PhD Thesis, Curtin University of Technology, Perth.

DITR (2006) Biodiversity Management. Leading Practice Sustainable Development Program for the Mining Industry Handbook. Dept. of Industry Tourism and Resources, Canberra, Australia.

EMRC (2004) Development of rehabilitation completion criteria for native ecosystem rehabilitation on coal mines in the Bowen Basin. Australian Coal Association Research Program Project C12045.

EMRC (2005) Development of rehabilitation completion criteria for native ecosystem rehabilitation on coal mines in the Hunter Valley. Australian Coal Association Research Program Project C13048.

EMRC (1999) PT Kaltim Prima Coal: A recommended monitoring program for areas rehabilitated following coal mining operations at Sangatta, East Kalimantan. Consulting report prepared for PT Kaltim Prima Coal, Sangatta, East Kalimantan, Indonesia. June 1999.

Fox, B.J. (1996) Long-term studies of small-mammal communities from disturbed habitats in eastern Australia. In M.J. Cody and J.A. Smallwood (eds) Long-term Studies of Vertebrate Communities. Academic Press, San Diego, pp. 467-501.

ICMM (2005) Biodiversity Offsets - a briefing paper for the mining industry. Report prepared by the International Council on Mining and Metals, London.

ICMM (2006) Good Practice Guidance for Mining and Biodiversity. International Council on Mining and Metals, London.

Jasper, D.A., Nichols, O.G. and Veneklaas, E. (2003) A review of indicators of success for rehabilitated tropical forest systems. Report to Misima Mines Limited prepared by Outback Ecology Services, February 2003. Perth, Western Australia.

Jasper, D.A., Veneklaas, E., Nichols, O.G. and Tongway, D.J. (2006) Indicators of success for mine site restoration in tropical moist forest ecosystems. In A.B. Fourie and M. Tibbett (2006) Mine Closure 2006. Proceedings of the 
First International Seminar on Mine Closure, 13-15 September 2006, Perth, Western Australia. Australian Centre for Geomechanics, University of Western Australia, pp. 719-731.

Majer, J.D., Day, J. E., Kabay, E.D. and Perriman, W.S. (1984) Recolonization by ants in bauxite mines rehabilitated by a number of different methods. Journal of Applied Ecology 2, pp. 355-375.

Majer, J.D. (1992) Ant recolonization of rehabilitated bauxite mines of Poços de Caldas, Brazil. Journal of Tropical Ecology 8, pp. 97-108.

Majer, J.D. (1996) Ant recolonization of rehabilitated bauxite mines at Trombetas, Para, Brazil. Journal of Tropical Ecology 12, pp. 257-273.

Majer, J.D., Orabi, G. and Bisevac, L. (2006) Incorporation of terrestrial invertebrate data in mine closure completion criteria adds sensitivity and value. In A.B. Fourie and M. Tibbett (eds) (2006) Mine Closure 2006. Proceedings of the First International Seminar on Mine Closure, 13-15 September 2006, Perth, Western Australia. Australian Centre for Geomechanics, University of Western Australia, pp. 709-717.

Majer, J.D., Brennan, K.E. and Moir, M.L. (2007) Invertebrates and the restoration of a forest ecosystem: 30 years of research following bauxite restoration in Western Australia. Restoration Ecology 15(4)(Supplement), pp. S104-S115.

Nichols, O.G. (1998) The development of a rehabilitation program designed to restore a jarrah forest ecosystem following bauxite mining in south-western Australia. In H.R. Fox, H.M. Moore and A.D. McIntosh (eds). Land Reclamation. Achieving Sustainable Benefits. Proceedings of the Fourth International Conference of the International Affiliation of Land Reclamationists, Nottingham, United Kingdom, 7-11 September 1998. A.A. Balkema, Rotterdam, pp. 315-325.

Nichols, O.G. (2006) Developing completion criteria for native ecosystem reconstruction - a challenge for the mining industry. In A.B. Fourie and M. Tibbett (2006) Mine Closure 2006. Proceedings of the First International Seminar on Mine Closure, 13-15 September 2006, Perth, Western Australia. Australian Centre for Geomechanics, University of Western Australia, pp. 61-74.

Nichols, O.G. and McIntosh, K. (1998) Techniques used by Alcoa to create wetland ecosystems following clay mining near Perth, Western Australia. In A.J. McComb and J.A. Davis (eds), Wetlands For the Future - contributions from INTECOL's V International Wetlands Conference. Gleneagles Publishing, Adelaide. pp. 701-718.

Nichols, O.G. and Foot, P. (2002) Designing a vegetation monitoring program to achieve continual improvement and assess the long term sustainability of mine rehabilitation. Proceedings of the Minerals Council of Australia Sustainable Development Conference and 27th Annual Environmental Workshop, Newcastle 10-15 November 2002. pp. 79-88.

Nichols, O.G. and Nichols, F.M. (2003) Long-term trends in faunal recolonization after bauxite mining in the jarrah forest of south-western Australia. Restoration Ecology 11, pp. 261-272.

Nichols, O.G. and Grant, C.D. (2007) Vertebrate fauna restored of rehabilitated bauxite mines - key findings from almost 30 years of monitoring and research. Restoration Ecology 15(4)(Supplement), pp. S116-S126.

Passell, H.D. (2000) Recovery of bird species in minimally restored Indonesian tin strip mines. Restoration Ecology 8 , pp. 112-118.

Umwelt (2003) Mount Owen Operations Biodiversity Offset Strategy. Report prepared for Hunter Valley Coal Corporation by Umwelt Environmental Consultants.

Xstrata Coal (2006) Mount Owen Complex Flora and Fauna Management Plan. 